\title{
Nehéz a döntés: jogerőre emelkednek vagy véglegessé válnak a büntetés-végrehajtási bírói határozatok? Boda Zoltán ${ }^{*}$
}

\begin{abstract}
A jogerö lényege, hogy a bíróság elé került ügyek, a törvények adta keretek között véglegesen befejezödjenek. Ugyanakkor különösen a bv. birói határozatokkal összefüggésben nagyon eltéró értelmezések alakultak ki, hogy milyen határozatok lehetnek képesek jogeröre. Ez az egyszerünek tünö, azonban mégis rendkívül bonyolult kérdéskör olyan további fogalmak részletezését és elemzését teszi szükségessé, mint alaki vagy anyagi jogerö, res iudicata (ítélt dolog), kötelezö erö, kötöerö, megváltoztathatatlanság. A kérdéskört az alapvetö jogokat sértö elhelyezési körülmények miatti kártalanitás tárgyában született határozatokkal összefüggésben is vizsgálat tárgyává teszem. Ennek az is az oka, hogy a tárgykörben született Kúriai határozatok és Alkotmánybírósági határozatok is kártalanitással kapcsolatos bv. ügyek kapcsán születtek.
\end{abstract}

Kulcsszavak: jogerö, véglegesség, jogbiztonság, kártalanitás, itélt dolog, kötelező erō, büntetésvégrehajtás

\section{Difficult decision: sentence enforcement court decision becomes final or takes binding legal} effect?

The essence of the legal force is that the cases brought before the court are finally concluded within the framework provided by law. Despite the previous statement, it is still not obvious which decisions bear legal force with special regards to law-enforcement judges' decisions. This is a seemingly simple, yet extremely complex issue which necessitates the analysis of legal concepts like: formal or substantive legal force, res iudicata, compulsive nature of decisions, binding nature of decisions and invariability. The paper also examines the issue with respect to judicial decisions in compensation cases initiated based on accommodation conditions that violate fundamental rights. The reason for the previous analysis is that the disputed decisions of the Supreme Court and the Constitutional Courts were made in such cases.

Keywords: legal force, finality, legal certainty, compensation, judgement, compulsive nature, lawenforcement

DOI: $10.32980 / M J S z .2021 .1 .954$

Treményeim szerint az alább megfogalmazott gondolatokkal sikerülni fog hozzájárulnom ahhoz, hogy egy újabb tudományos vita és diskurzus vegye kezdetét a jogerő akár jogágakon is átívelő dogmatikája kapcsán - azzal, hogy igyekszem komplex módon, sokoldalúvá téve, a jogerő intézményével felmerülö kérdéseket több szempontból és egymással való összefüggésükben is megvizsgálni.

Talán elsőre marginálisnak tünhet a büntetés-végrehajtási bírói határozatok jogerőképességéről tanulmányt írni, azonban úgy vélem, hogy a jogbiztonság

\footnotetext{
* Bírósági titkár, Debreceni Törvényszék
} 
szempontjából mégis a jogalkalmazás számára nélkülözhetetlen a különböző ügyekben keletkezett döntések - így a bv. bírói döntések - joghatásáról értekezni (a hatályos szabályozás és a jogalkalmazás szabta keretek között keresve a korrekt szakmai válaszokat), mert ez a hatás járul leginkább hozzá az említett jogbiztonsághoz, amely a jogállami demokráciák kiindulópontja. A jogerőről először Ulpianus írt a közismerté vált kijelentésével, mely szerint: „Res iudicate pro veritate accipitur" (az ítélt dolog .... elfogadtatik). Ezzel nagyon árnyaltan érzékelteti a bírói ítélet igazságtartalmával kapcsolatos kérdéskört is - amely a büntetőeljárás céljával kapcsolatos érték is -, ugyanis nem azt mondja ki, hogy az ítélt dolog feltétlen módon igaz, és e miatt végleges és megfellebbezhetetlen, hanem "csak" azt, hogy ítélt dolgot igaznak és véglegesen eldöntöttnek kell tekinteni. A jogerő intézménye, azt a célt szolgálja, hogy a bíróság elé került ügyek, a törvények adta keretek között véglegesen befejeződjenek ${ }^{1}$, ugyanakkor ahogyan ezt igyekszem szemléltetni, különösen a bv. bírói határozatokkal összefüggésben nagyon eltérő értelmezések alakultak ki annak kapcsán, hogy milyen határozatok képesek jogerőre. Ez az egyszerűnek tűnő, azonban jómagam részéről mégis rendkívül bonyolultnak értékelt kérdéskör olyan további fogalmak részletezését és elemzését teszi szükségessé, mint alaki vagy anyagi jogerő, res iudicata (ítélt dolog), kötelező erő, kötőerő, megváltoztathatatlanság.

A kérdéskört az alapvető jogokat sértő elhelyezési körülmények miatti kártalanítás tárgyában született határozatokkal összefüggésben is vizsgálat tárgyává teszem. Ennek az is az oka, hogy a tárgykörben született Kúriai határozatok és Alkotmánybírósági határozatok is kártalanítással kapcsolatos bv. ügyek kapcsán születtek.

A büntetőeljárás - és ezzel szerintem szoros összefüggésben a büntetésvégrehajtási eljárások ${ }^{2}$ - céljaként sokszor olyan értékek is megjelennek, mint az igazságosság ${ }^{3}$, a jogbiztonság vagy a jogbéke fogalmai. Joggal feltételezi a társadalom, hogy a jogerős ítélet (vagy egyéb határozat) megfelel az igazságosság követelményének. ${ }^{4}$ Ezt a "Res iudicata pro veritate habetur" jogi tétel fejezi ki, mely szerint tehát a jogerős ítéletet igaznak kell tartani. ${ }^{5} \mathrm{Az}$ igazsággal (vagy „,igazságossággal") kapcsolatban a büntetőeljárási törvényben is találunk

\footnotetext{
${ }^{1}$ Elek Balázs: Jogerő a büntetőeljárásban. Debrecen, Debreceni Egyetem Állam és Jogtudományi Kar, 2012, 9. o. kiegészítve

2 lásd a büntetések, az intézkedések, egyes kényszerintézkedések és a szabálysértési elzárás végrehajtásáról szóló 2013. évi CCXL. törvény (továbbiakban: Bv. tv.) 50.§ (6) bekezdése szerint: ha e törvény, vagy más törvény eltérően nem rendelkezik, a büntetés-végrehajtási bíró eljárására a büntetőeljárás szabályait kell alkalmazni azzal, hogy bizonyítási indítvány előterjesztésére vonatkozóan a Be. 520. § nem alkalmazható és előkészítő ülés megtartásának nincs helye.

3 Tremmel Flórián megfogalmazása alapján az igazság kiderítése lehet a büntetőeljárás legfőbb célja: „[S]ok szempontból a jogerős bírósági döntés, bár lehetnek némi hiányosságai, hibái, az igazság erejével bír, mondhatni erősebbnek mutatkozik a valóságnál is." (Tremmel Flórián: Magyar büntetőeljárás. Budapest-Pécs, Dialóg Campus Kiadó, 2001, 457. o.);

lásd még: „Aliud nihil in iudiciis quam iustitiam locum habere debet." vagyis: „A bírósági eljárás célja nem lehet más, mint az igazság felderítése." (Nótári Tamás: A jognak asztalánál... 1111 jogi regula és szentencia latinul és magyarul. Budapest, Magyar Közlöny Lap- és Könyvkiadó, 2008, 16. o.)

${ }^{4}$ Elek: i.m. 11. o.

${ }^{5}$ Takács György: Ha a jogász latinul beszél. Budapest, KJK Kiadó, 1991, 216. o.
} 
rendelkezést. A régi Be. (1998. évi XIX. törvény) is rendelkezett róla a 12.§ (1) bekezdésében, amikor kimondta, hogy a bíróság feladata az igazságszolgáltatás, a 75. § (1) bekezdése pedig azt is rögzítette, hogy a bizonyítás során a tényállás alapos, hiánytalan, a valóságnak megfelelő tisztázására kell törekedni. Az új Be. (2017. évi XC. törvény) már a preambulumában azt szögezi le, hogy „[[..] [s]zem előtt tartva az igazság megállapításának igényét". A $11 . \S$ a régi Be. 12.§-ában foglaltakkal egyezően rögzíti a bíróság feladatát, az igazságszolgáltatást. A bizonyítás általános szabályai körében pedig a 163. § (2) bekezdése kimondja, hogy a büntetőeljárásban a bíróság, az ügyészség és a nyomozó hatóság a döntését valósághü tényállásra ${ }^{6}$ alapozza.

$\mathrm{Az}$ igazság (igazságosság) mellett azonban megjelenik a jogerővel összefüggésben a jogbiztonság védelme is - mint a jogrend fenntartására irányuló tevékenység egyik eszköze ${ }^{7}$. A jogerő ugyanis

- hivatott arra, hogy megakadályozza a vég nélküli jogviszonyokat és az ezzel együtt járó bizonytalanságot, hiszen

- a „feladata" a jogviszonyok jövőbeli biztosítása, valamint

- az adott eljáráson túlmenő hatásként "ne bis in idem" érvényre juttatása8;

- biztosítja továbbá a jogrend stabilitását, az állami akarat, a törvények érvényesítését, végezetül

- biztosítja a döntés végrehajthatóságát, megtámadhatatlanságát, megváltoztathatatlanságát.

Ugyanis, ha a bíróságok büntetőítéleteit (vagy egyéb határozatait) korlátlanul kétségbe lehetne vonni, az aláásná a törvények, az állami akarat érvényesítését, a jogbiztonságba vetett bizalmat, és kétségessé tenné az állami szervek eljárásának értelmét. ${ }^{9}$

Úgy vélem tehát, hogy a jogerőről való értekezés nem „felesleges elmélkedés": a bíróság feladataként az igazságszolgáltatást legmagasabb jogforrási szintem nem a büntetőeljárási törvény, hanem korábban az Alkotmány ${ }^{10}$, ma pedig az Alaptörvény ${ }^{11}$ határozza meg. Ezzel összefüggésben említést érdemel, hogy az Alaptörvényben kifejezetten is deklarált hatalommegosztás elve alapján végzett igazságszolgáltatás az a tevékenység, amelyet kizárólag a bíróságok végezhetnek, azt sem a törvényhozó, sem a végrehajtó hatalom nem gyakorolhatja. Ha a jogerős döntést kell igaznak elfogadni, akkor az igazságszolgáltatás fogalmához kapcsolódó igazságosság, jogbiztonság és jogbéke fogalmaival való összekapcsolódás is kétségbe vonható akkor, ha már önmagában a jogerő kérdésessé válik (mint ahogy azt alább a bv. bírói határozatokkal összefüggésben szemléltetni kívánom). A jogbiztonság, mint az igazság(osság)hoz és a jogerőhöz való viszonyulási pont

\footnotetext{
${ }^{6}$ Ennek a jogalkalmazási gyakorlatban való értelmezése külön értekezés témája is lehet.

${ }^{7}$ Elek: i.m. 14. o.

${ }^{8}$ Elek: i.m. 11. o. ; lásd bővebben: Wiener 2003., Wiener A. Imre: A Ne Bis In Idem elv érvényesítéséről. Büntetőjogi Kodifikáció, 1-2/2003. 62-68. o.; Tarr Ágnes: A ne bis in idem elv az Európai Bíróság gyakorlatában. Miskolci Jogi Szem/e, 2007, 2. szám. 100-118. 0.

${ }^{9}$ Király Tibor: Büntetőeljárási jog. Budapest, Osiris Kiadó, 2000, 494-498. o.

1045 . $\S(1)$ bekezdés

${ }^{11} 25$. cikk (1) bekezdés
} 
alkotmányos tartalmát már az Alkotmánybíráság működésének kezdetén, a 9/1992. (I. 30.) AB határozatában ${ }^{12}$ fektette le. Többek között kiemelte a testület, hogy "[ $[\mathrm{A}] \mathrm{z}$ anyagi igazságosság jogállami követelménye a jogbiztonságot szolgáló intézményeken és garanciákon belül maradva valósulhat meg." Pontosan ilyen intézmény, illetve garancia a jogerő intézménye.

$\mathrm{Az}$ alapvetően a büntetőeljárással összefüggésben született jogerö-definíciók mind-mind rávilágítanak arra, hogy mennyi „elemből” tevődik össze a jogintézmény és, hogy ahhoz milyen szerteágazó hatások (,jelenségek") járulnak:

- Király Tibor szerint a jogerő lényege a határozat véglegességében ragadható meg, ami az elítéltek szempontjából azt jelenti, hogy tovább a terhükre azt megváltoztatni nem lehet, a sorsuk eldőlt, azaz a határozat perorvoslattal többé nem támadható és meg nem változtatható. A jogerőhöz füződő hatások közé a határozat megváltoztathatatlanságát, a kötelező erőt, a végrehajthatóságot, a bizonyító erőt sorolja fel. Király azonban a kötőerőt különböző fogalomként kezeli. ${ }^{13}$

- Farkas Ákos a jogerő fogalma alatt érti a határozat megváltoztathatatlanságát, amely szerinte azt jelenti, hogy rendes jogorvoslattal már nem támadható, nem változtatható meg, csupán rendkívüli perorvoslat útján. Ebben az értelmezésben tehát a megváltoztathatatlanság és a megtámadhatatlanság egybefonódik. A jogerő fogalmának további részeiként sorolja még a kötelező erőt, a res iudicata-t (ítélt dolog hatás), a végrehajthatóságot, a bizonyító erőt és - pl. Királlyal szemben - a kötőerőt is. ${ }^{14}$

- Tremmel Flórián a jogintézményhez füződő hatások körében a következőket nevesíti: egyszerű kötőerő (szerinte már a jogerőre emelkedés előtt is köti a határozatot hozó bíróságot, és a résztvevőket); a minősített kötőerő - ami azt jelenti, hogy minden hatóságot és magánszemélyt köt -; a kizáró hatás (ne bis in idem), a "lezáró" hatás, mint a döntés irányadó volta; a bizonyító erő; és a végrehajthatóság. ${ }^{15}$

- Herke Csongor egy ítélet jogerején a meghozott döntés véglegességét és irányadó voltát érti. Külön kitér arra is, hogy a jogerő anyagi értelemben a döntés tartalmára vonatkozik, és kimondja, hogy egy tett, amelyet a lezárult eljárásban hozott ítélet érint, nem lehet még egyszer büntetőeljárás tárgya. $A z$ anyagi jogerőnek szerinte tehát lezáró hatása van, ami a formális jogerő következménye, és akkor áll be, ha az ítélet többet már nem megtámadható. ${ }^{16}$

\footnotetext{
${ }^{12} \mathrm{~A}$ határozat egyéb, jogbiztonsággal és jogerővel kapcsolatos összefüggéseit lásd lentebb.

${ }^{13}$ Király (2000) i.m. 494.

${ }^{14}$ Farkas Ákos-Róth Erika: A büntetőeljárás. Budapest, Complex Wolters Kluwer Csoport, 2007, 319. o.

${ }^{15}$ Tremmel: i.m. 457.

${ }^{16}$ Herke Csongor: Súlyositási tilalom a büntetöeljárásban. Pécs, PTE ÁJK, Monográfia, 2010, 150. o.; Elek: i.m. 79. o.
} 
- Angyal Pál definíciója - mely az egyik legrégebbi a hazai jogirodalomban szerint a jogerő (tágabb értelemben vett meghatározása szerint) valamely konkrét életviszonyra vonatkozó elrendezésnek az a hatálya, melynél fogva az minden irányban az objektív jog tekintélyét élvezi. Angyal szerint a perben több vitás kérdés merülvén fel a felek között, ezeknek minden irányban való jogszempontú, végleges eldöntése az arra hivatott bíróság részéről szintén oly elrendezése a vitás jogviszonynak, mely az objektív jog erejével hat. Erre tekintette pedig a perbeli vitás jogviszonyt végérvényesen elrendező bírói határozatnak ezt a minden irányban érvényesülő hatályát nevezi szűkebb értelemben vett jogerőnek. ${ }^{17}$

A nem egységes meghatározásokra figyelemmel Elek Balázs - további olyan alábontást is adva a fogalomhoz, amelynek nagy jelentősége van (lásd: anyagi/alaki jogerő) - a következőket írja a jogerő intézményéről:

"[...] [ú]gy vélem, hogy a jogeröröl egységes definíciót nem is lehet adni, mert mást és mást takar az ügydöntö, és a nem ügydöntö, de fellebbezéssel támadható határozatok jogereje. Ezen két kategóriát is külön lehet bontani anyagi és alaki (vagy formális) jogeröre, melyek együttesen adják az adott kategória (ügydöntő és nem ügydöntő) jogerőfogalmát. Az ügydöntó határozatok jogereje jelenti a büntetöjogi igényröl történt végleges, megváltoztathatatlan döntést, amely mindenki számára irányadó, valamint megcáfolhatatlanul kötelezö, és rendes perorvoslattal már nem támadható. Az ügydöntő határozatok jogerejének nem része, csak elöfeltétele a visszavonhatatlanság, de a végrehajthatóságnak már a jogerö az elöfeltétele. Nem mellőzhetö annak rögzítése sem, hogy a jogerös ügydöntö bírósági határozat fogalmán az adott büntetöügyben keletkezett elsö-, másod- és harmadfokú határozatot együttesen kell érteni, és azok együttes tartalma adja a bírósági döntést. Az egyéb jogeróképes határozatok jogereje az adott perjogi kérdésben történt végleges, megváltoztathatatlan, mindenki számára irányadó és kötelező (végrehajthatóságtól független), perorvoslattal már nem támadható döntést jelent. Ezen felül léteznek a csak alaki jogeröképes határozatok, amelyeknek a jogereje a megtámadhatatlanságot jelenti."18

A fentebb említett anyagi/alaki jogerő megkülönböztetés rövid említése azért is nélkülözhetetlen, mert az később nagy jelentőséghez jut az alább részletezett Kúriai határozatokban és az Alkotmánybíróság határozatában is, és szerepet kell, hogy kapjon ennél fogva a jogalkalmazás mindennapos értelmezési gyakorlatában is.

Az anyagi jogerőhöz kapcsolódó magyarázatok közül Király Tibor szerint az föként abban áll, hogy a büntetőjogi főkérdésről való döntés után végrehajthatóvá válik a határozat, és beáll az újabb eljárás tilalma, hiszen az állam büntetőjogi igénye ugyanis kielégült, ha volt büncselekmény, és róla döntöttek. Kiemeli azt, hogy

\footnotetext{
${ }^{17}$ Angyal Pál: $A$ magyar büntető eljárásjog tankönyve. Budapest, Athenaeum Irodalmi és Nyomdai Rt., 1915, 239-242. o.; Elek: i.m. 78. o.

${ }^{18}$ Elek: i.m. 80. o.
} 
ügydöntő határozatoknál azonban az anyagi és alaki jogerő egyaránt jelen van, és gyakorlatilag nem választható szét. ${ }^{19}$

Soós László szerint az anyagi jogerő az alakilag jogerős határozatnak az a tulajdonsága, hogy a határozatban elbírált konkrét életviszony (cselekmény) végérvényesen elbírált, ítélt dolog (res

iudicata) lesz. ${ }^{20}$

Elek Balázs ezzel összefüggésben arra tett megállapítást, hogy az anyagi jogerő kérdése elsősorban a kimerített váddal, az elbírált cselekményre nézve állhat fenn, amikor a határozatban a bíróság véglegesen dönt a büntetőjogi igényről, a vád tárgyává tett cselekmény érdemi elbírálása keretében. ${ }^{21}$ Leszögezi, hogy véleménye szerint elsősorban az ítéletek és ügydöntő végzések képesek anyagi jogerőre, amelyek tartalmazzák az érdemi döntést és ebben az a gondolat nyilvánul meg, hogy mindazoknak a határozatoknak képesnek kell lenniük az anyagi jogerőre, amelyek a folyamatban végérvényesen és teljes terjedelemben döntenek, amelyek lezáró módon az érvényes állami büntetőjogi igény mellett foglalnak állást. Formális döntéseknél ez nem így van, mert azok egy leküzdhető akadályból adódnak, egyegy részletkérdésről döntenek. ${ }^{22}$

$A z$ anyagi jogerővel szemben a legtágabb értelemben vett meghatározás szerint az alaki (formális) jogerő nem más, mint a határozat ellen jogorvoslati kérelem előterjesztésének tilalma, vagyis az, hogy a határozat rendes jogorvoslattal nem támadható meg ${ }^{23}$, azonban a rendkívüli jogorvoslati eszközök lehetősége nem zárja ki a formális jogerő belépését ${ }^{24}$.

Király Tibor szerint a határozat megváltoztathatatlanságát szokás alaki jogerőnek is nevezni, de azon föként a határozatnak a rendes perorvoslattal való megtámadhatatlanságát érti. ${ }^{25}$ Soós László az alaki jogerőt a határozatnak azon tulajdonságaként értékeli, hogy jogorvoslattal nem támadható meg, és a határozat végrehajthatóvá válik. $A z$ alaki jogerő tulajdonsága közé sorolja a megtámadhatatlanságot, amit azonban nem tekint abszolútnak, mert az ítélet jogerőre emelkedése után csak a rendes jogorvoslattal való megtámadás lehetősége kizárt. ${ }^{26}$

Elek Balázs a fentiekből is levezetve azt írja az alaki jogerőről:

"[...] [ú]gy gondolom, hogy hogy szükségtelen lenne az alaki jogerö fogalmát bármely határozattípusnál a megtámadhatatlanságtól, a rendes jogorvoslatok kimeritésétól eltéróen meghatározni. A megtámadhatatlanság, azaz a további rendes jogorvoslat lehetöségének kizártsága csak az ügydöntö határozatokra,

\footnotetext{
${ }^{19}$ Király (2000): i.m. 494-498. o. alapján

${ }^{20}$ Elek: i.m. 84. o.

${ }^{21}$ Szerinte ez nem mond ellent annak, hogy létezhetnek olyan határozatok, amelyek nem ügydöntő határozatok, de mégis büntető anyagi jogi kérdést rendeznek el véglegesen. (Elek: i.m. 85-86. o.)

${ }^{22}$ Elek: i.m. 87. o.

${ }^{23}$ Hargitai József: Jogi fogalomtár. Budapest, Magyar Hivatalos Közlönykiadó, 2005, 748. o.; Holé Katalin - Kadlót Erzsébet (szerk.): A büntetöeljárásról szóló 1998. évi XIX. törvény magyarázata VII. kötet. Budapest, Magyar Hivatalos Közlönykiadó, 2010, 214-337. o.

${ }^{24}$ Elek: i.m. 89. o.

${ }^{25}$ Király (2000): i.m. 495. o.

${ }^{26}$ Berkes György (szerk.): Büntetőeljárási jog. Kommentár a gyakorlat számára. Budapest, HVG-ORAC Lap- és Könyvkiadó Kft., 2009, 588.§-hoz.; Elek: i.m. 91. o.
} 
és az egyéb jogeröképes határozatokra értendö. Vannak olyan határozatok, ahol a jogeró nem is jelenthet mást, mint az alaki jogerőt, például a kényszerintézkedésekröl döntő határozatoknál. Végül a pervezetö végzések azok, amelyeknek még alaki jogereje sincs."27

Összességében maga a jogerő - mint a jogállamiság lényegi elemét alkotó alkotmányos jogintézménye ${ }^{28}$ - elméleti alapja alátámasztható több módon is. Egyfelől felmerülhet, hogy a jogerő olyan, minden jogágra kiterjedő fogalom, amit a jogalkotónak nem is kell minden eljárási törvényben külön meghatározni, mert a hatóság döntései külön perbeli aktus nélkül is kötelező erővel lezárulnak. Más megközelítés szerint az egyes törvényeknek pontosan meg kell (vagy kellene) határozni a jogerő fogalmát, terjedelmét, hatókörét, és hogy az mely határozatoknál érvényesülhet, mert az eljáró hatóságok és határozataik különbözősége miatt nem állítható, hogy azok önmagukban hordozzák a jogerő képességét. ${ }^{29} \mathrm{~A}$ régi Be. két álláspont között helyezkedett el, hiszen rögzítette, hogy egyes határozatok mikor emelkedhetnek jogeröre, de nem tartalmazta egyértelműen, hogy melyek ezek a határozatok, azt sem, hogy milyen hatásokat rendel a jogerő mellé, és arról sem volt külön rendelkezés, hogy egyes határozati formáknál - a büntetőeljárás ugyanis különböző határozati formákat tartogat, s ezekben az a közös, hogy lezárják az adott eljárást - miben különbözik. Ennek jogpolitikai magyarázata szerint a jogerő intézményének belső létjogosultságát maga a per célja adja, azaz az, hogy valamely vitás jogi ügyet végleges elintézésre vigyen, és az érdekek ütköztetésének olyan szilárd és kötelező erejü alapot adjon, amely kizárja a per bármiféle folytatását, illetve megismétlését. Ebből következően pedig az ítélet, mint a per eredménye, a konkrét jog végérvényes megállapításához és kötelező érvényű döntéshez kell, hogy vezessen, mert ha ez nem valósulna meg, akkor az olyan ítélet, amely nem kötelező érvényü a felekre és a perben érintettekre nézve, ellentmondásban lenne a per céljával. ${ }^{30} \mathrm{Az}$ új Be. 456.§ (1) bekezdésében azonban konkrét, meghatározó jellegú szabályt rögzít a jogerórool: a bíróság jogerōs ügydöntő határozata végleges, mindenkire kötelezó döntést tartalmaz a vádról, illetve a terhelt büntetöjogi felelösségéröl, a büntetőjogi következményekröl vagy ezek hiányáról. Rögzíti a bekezdés második mondatában, hogy az ügydöntö határozat a jogeröre emelkedését követöen kizárólag rendkívüli jogorvoslattal vagy különleges eljárás eredményeként változtatható meg. A jogerőhöz kapcsolódó „hatásokat” pedig a (2), (3) és (4) rögzíti a következők szerint: (2) bek.: ha a vádról rendelkező ügydöntő határozat ${ }^{31}$ jogerőre emelkedik, az abban elbírált cselekmény miatt a terhelttel szemben újabb büntetőeljárás nem folytatható;

(3) bek.: az ügydöntő határozat jogerőre emelkedését követően kell a kiszabott büntetés vagy az alkalmazott intézkedés végrehajtását megkezdeni, az abban

${ }^{27}$ Elek: i.m. 92. o.

28 42/1993. (VI.30.) AB határozat

${ }^{29}$ Elek: i.m. 72. o.

${ }^{30}$ Elek: i.m. 72-73. o.

${ }^{31}$ A 2020. május 29. napján kihirdetett, a büntetőeljárásról szóló törvény és más kapcsolódó törvények módosításáról szóló 2020. évi XLIII. törvény 271.§ 83. pontja módosította a korábban hatályban volt szöveget a 456. § (2) bekezdésében akként, hogy az "az ügydönto”" szövegrész helyébe az "a vádról rendelkező ügydöntő" szöveg került. 
foglaltakat teljesíteni, illetve a jogerőre emelkedést követően állnak be az elítéléshez, a felmentéshez vagy az eljárás megszüntetéséhez füződő jogkövetkezmények; (4) bek.: a jogerős ügydöntő határozatban kiszabott büntetés vagy alkalmazott intézkedés végrehajtását, illetve az abban foglaltak teljesítését az e törvényben meghatározott esetekben a bíróság felfüggesztheti vagy félbeszakíthatja.

A szabályozáshoz füződő kommentár ${ }^{32}$ szerint az új Be. egyik jelentős újítása, hogy bevezeti a jogerő fogalma mellett a véglegessé válás fogalmát, valamint hozzájuk kétféle záradékot rendel, egyrészt a jogerősítési, másrészt a véglegessé válási záradékot. Az új eljárási kódex a jogerő fogalmát pontosan meghatározza, az anyagi és az alaki jogerő dogmatikai hátterét alapul véve szabályozza a jogerő véglegessé válásának új rendszerét és a fogalmi elemek alapján került egyértelmüen meghatározásra az, hogy az egyes határozattípusok jogerőssé vagy véglegessé válhatnak. Alapvetően a 9/1992. (I. 30.) $A B$ határozat ${ }^{33}$ hívta fel a figyelmet különbségtétel szükségességére, amely úgy rendelkezik, hogy:

"[A]z anyagi igazságosság és a jogbiztonság követelményét a jogerő intézménye hozza összhangba - megint csak a jogbiztonság elsődlegessége alapján. A jogerő intézménye, alaki és anyagi jogeröként való pontos meghatározottsága a jogállamiság részeként alkotmányos követelmény." Továbbá határozottan rögzíti, hogy "[...] [a] jogorvoslati lehetöségek mellett beállott jogerő tiszteletben tartása a jogrend egészének biztonságát szolgálja". Hangsúlyozza, hogy a "[...] [j]ogállamiság lényeges eleme, hogy a törvénynek egyértelmüen meg kell határoznia, mikor támadható meg egy birósági határozat rendes fellebbviteli jogorvoslattal, illetve, hogy a jogerössé vált határozat megtámadására milyen feltételek alapján van lehetöség, s hogy mikor következik be az az állapot, amikor a jogerós határozat már semmiféle jogorvoslattal nem támadható". A jogbiztonság maradéktalan érvényesülése érdekében teszi szükségessé, hogy „[...] [a] jogerös határozat - az eldöntött kérdés személyi és tárgyi keretei között - irányadóvá váljék mind az eljárásban résztvevőkre, mind a később eljáró bíróságra, illetőleg más hatóságra". ${ }^{34}$

A 2/2015. büntető jogegységi határozat ${ }^{35}$ is foglalkozik az anyagi jogerő-alaki jogerő problematikájával, anyagi jogerőként határozza meg az ügy tárgyának végleges, minősített kötőerővel való lezárását, ami tulajdonképpen ítélt dolgot (res iudicata)

32 Kommentár a büntetőeljárásról szóló 2017. évi CX. törvényhez - Főszerkesztő: Polt Péter (továbbiakban: kommentár)

${ }^{33}$ Egyebekben az Alkotmánybíróság ezzel a határozatával azt is megállapította, hogy a törvényességi óvás jogintézménye alkotmányellenes és ezért a törvényességi óvás emelésére vonatkozó jogszabályi rendelkezéseket 1992. december 31-i hatállyal megsemmisítette. [Lichtenstein András: A törvényesség érdekében bejelentett jogorvoslat elmélete és gyakorlata. Eljárásjogi Szem/e, 2018. évfolyam / 2018/4. https://eljarasjog.hu/2018-evfolyam/a-torvenyesseg-erdekeben-bejelentett-jogorvoslat-elmelete-esgyakorlata/ (2021-01-21)]

34 9/1992. (I. 30.) AB határozat V./4. pont

${ }^{35} \mathrm{~A}$ határozatot egyebekben eljárás-dogmatikai szempontból többen is kifogásolták. [lásd: Király Eszter: A jogerő színeváltozása az új büntetőeljárási törvényben. Eljárásjogi Szem/e, 2017. évfolyam/ 2017/4. https://eljarasjog.hu/2017-evfolyam/a-jogero-szinevaltozasa-az-uj-buntetoeljarasi-torvenyben/ (202101-21)] 
jelent. Az alaki jogerőt pedig egyszerű kötőerőként definiálja, amely kizárólag a határozat rendes jogorvoslattal való megtámadhatóságának kizárásával jár. ${ }^{36}$

Az anyagi-alaki jogerő kapcsán a kommentár azt írja le, hogy a jogerő a Be.-ben az anyagi jogerót jelenti (!). Az anyagi jogerö pedig csak az ügydöntó határozathoz kapcsolódhat, hiszen az ügydöntö határozat rendelkezhet az ügy érdeméröl, az tartalmaz végleges, mindenkire kötelezö döntést a vádról, illetve a terhelt büntetöjogi felelösségéröl, a büntetőjogi következményekröl vagy ezek hiányáról. Az ügydöntő határozat a jogeröre emelkedését követően föszabály szerint megváltoztathatatlan, rendes jogorvoslattal nem támadható meg és a jogerő feloldását a Be. csak rendkívüli jogorvoslat, illetve különleges eljárás útján teszi lehetővé. A kommentár elkülönítése szerint az ügydöntő határozat egyrészt az ítélet, másrészt az ügydöntő végzés [Be. 449. § (2) bekezdés] és a jogszabály egyértelmü iránymutatást ad arra nézve, hogy a bíróság mely határozatai emelkednek jogerőre, illetve válnak véglegessé: az ügydöntő határozat jogeröre emelkedik, a nem ügydöntő végzés pedig véglegessé válik. A véglegessé válás az alaki jogerő ${ }^{37}$ fogalmi meghatározására szolgál.

A jogerő az ügydöntő határozathoz pozitív és negatív hatást kapcsol. Előbbit a jogirodalom a "res iudicata" kifejezéssel illeti, azaz ítélt dolog, a döntés végleges, mindenkire irányadó, tovább nem vitatható, ez pedig a Be. 456. § (1) bekezdésében kerül szabályozásra. Utóbbin a „ne bis in idem” elvet érti, azaz a kétszeres eljárás tilalmát, ami a Be. 456. § (2) bekezdésében foglaltaknak felel meg. Ez alapján, ha egy büntetőügyben jogerős ügydöntő határozat született, akkor újabb büntetőeljárás nem folytatható ugyanazon terhelttel szemben, ugyanazon (az ügydöntő határozatban elbírált) cselekmény miatt. ${ }^{38}$

A 2020. évi XLIII. törvény 271.§-ához füzött végső előterjesztői indokolás a következőket rögzíti.

"[A] Be. a bírósági döntések és intézkedések rendszerszintü szabályozásának célzatával alkotta meg a bíróság által meghozható határozatok kategóriáit, és azokat a tartalmat kifejezó megnevezéssel látta el. A bírósági határozatok törvényi felosztása a döntés tartalmi elemeire, mint a büntetőjogi felelösségben való állásfoglalás, a szankció kiszabás, továbbá a megtámadhatóság, illetve a végrehajthatóság szempontjaira tekintettel tesz különbséget az ügydöntö határozat és a nem ügydöntö végzés között, egyúttal az ügydöntö határozathoz csatolva a

${ }^{36}$ Ez a ma is hatályban lévő jogegységi határozat gyakorlatilag kibővítette a törvényesség érdekében bejelentett jogorvoslattal támadható határozatok körét, azonban az új Be. hatálybalépésével - annak megváltozott jogerőfelfogása okán - Lichtenstein András véleménye szerint a neki tulajdonított jelentősége csökkent. (Lichtenstein: i.m.)

${ }^{37}$ A kommentár szerint ,[...] [t]ermészetesen egy jogerős ügydöntő határozatnak része az anyagi jogerő mellett az alaki jogerő is, az anyagi jogerő a tágabb fogalom (a határozat megváltoztathatatlansága), amely magában foglalja az alaki jogerőt (a határozat megtámadhatatlansága) is, tulajdonképpen az anyagi jogerő az alakilag jogerős határozatnak az a tulajdonsága, hogy az adott cselekmény végérvényesen elbírálásra került, ítélt dolog."

${ }^{38}$ Mindezek mellett ugyanakkor indokoltnak tartja megjegyezni a kommentár, hogy a Be. rendszerében nem minden ügydöntő határozat rendelkezik a büntetőeljárás megindításának alapjául szolgáló cselekmény érdemi elbírálásáról. Így az ügydöntő határozatokhoz - függetlenül azok jogerőképességétől - nem minden esetben társul az ítélt dolog (res iudicata), illetve a ne bis in idem intézménye, amely csupán a cselekményt érdemben elbíráló ügydöntő határozatok következménye. 
jogerö intézményét. A megkülönböztetésnek a megnevezésben megnyilvánuló módja azonban jelentös zavart keltett a jogalkalmazás széles körében. Az 1998-as $B$ e. is használta ugyanis az ügydöntö határozat fogalmát, azonban nem definiálva, vagy meghatározva az e fogalom alá tartozó határozat fajtákat mint azt a Be. teszi, hanem oly módon, mely szerint a bíróságnak az ügydöntő határozatban a vádról határoznia kell. Az 1998-as Be. rendszerében tehát a szabályozásból kiolvashatóan az ügydöntő határozat fogalma kizárólag a vádról érdemben rendelkezö határozatok gyüjtömegnevezése volt, szemben a Be. tágabb, a döntés formai megjelenésére is érzékeny kategória megnevezésével. A vádról való döntés szorosan kapcsolódik az itélt dolog vagyis a res iudicata intézményéhez, mely utóbbi kézzel fogható definiálása ugyan nem lelhetö fel sem az 1998-as, sem a hatályos Be.-ben, az intézményt kitöltö tartalmon azonban a hatályos Be. sem kívánt változtatni. $A$ biróságnak, amikor a vádról rendelkezik, a vád tárgyává tett magatartás megtörténtéröl vagy meg nem történtéröl kell állást foglalnia, a történtek mikéntjét kell megállapítania, továbbá ennek jogi következményeit kell levonnia és kizárólag ehhez kapcsolódhat az itélt dolog jogintézménye is, mely a jogtudományban a jogeró fogalomhoz tartozik. A Be. ugyanakkor nem kívánta a res iudicatat az ügydöntó határozat kategóriájába tartozó döntések mellé sem kapcsolni, vagyis a Be. szabályozásában nem minden ügydöntö határozat eredményez res iudicatat. Ez a jogalkalmazás körében azon jogintézményeket illetően okozott szembetünó problémát, ahol a jogintézmény léte kizárólag res iudicitára képes ügydöntó határozatok esetében értelmezhetö, mint a perújitás vagy a felülvizsgálat. A kialakult jogalkalmazási probléma a Be. által elvégzett terminológiai tisztitás eredményeként rögzített, a biróság döntéseire használt klasszikus fogalmak megváltoztatását nem teszi indokolttá. Ugyanakkor miután a Be. nem kivánt azon a koncepción változtatni, hogy a res iudicata kizárólag olyan jogerös ügydöntö határozathoz kapcsolódhat, amely büntetöeljárás megindításának alapjául szolgáló cselekményt birál el [Be. 456. § (2) bekezdés], és csak az ilyen ügydöntö határozat képezheti tárgyát a rendkivüli jogorvoslatoknak, az egyértelmüség követelménye ennek a jogszabályban való megjelenitését kívánja meg."

Fentieket összegezve arra tehetünk megállapítást, hogy az új büntetőeljárási törvény kellő részletességű és kimerítő jellegű magyarázattal szolgáló fogalommeghatározást ad arról, hogy a büntetőeljárásban mely határozatokat kell jogerőképes ügydöntő határozatnak tekinteni és melyeket kell ezzel ellentétben jogőre nem képes, hanem véglegessé váló, nem ügydöntő határozatnak tekinteni. Ugyanakkor - és jelen tanulmány megírásának is ez szolgált fö okául - azt is látnunk kell, hogy az ítélet (mint egyértelmúen ügydöntő határozat) egy új jogviszonyt is létrehoz, méghozzá az állam és az elítélt között, amely nem más, mint a büntetésvégrehajtási jogviszony. Azonban ennek kapcsolata a jogerővel közel sem olyan egyértelmü - mint ahogy ennek bemutatására törekszem. A Bv.tv. pedig sajnálatos módon - és talán ez nem erős megfogalmazás - nem használja olyan következetesen az egyes határozatokhoz kapcsolódó "jogerős" és "ügydöntő" fogalmakat, mint a büntetőeljárási törvény. A Bv.tv. szerinti értelmezéshez kapcsolódó sok eltérő vélemény és ennek nyomán kialakult gyakorlat ismertetésére törekszem az alábbiakban azzal az igénnyel, hogy rávilágítsak arra, hogy ezen 
problémát sürgősen, jogalkotási szinten lenne szükséges rendezni. Kiindulási alapként a Bv.tv. következő rendelkezéseit szükséges beidézni:

"50. $\mathcal{S}(1)$ A büntetés-végrehajtási bíró

f) az e fejezetben szabályozott eljárása során az ügy érdemében - ide nem értve a bírósági felülvizsgálati eljárást - ügydöntö végzést hoz, amely ellen

fa) - e törvény eltérö rendelkezése hiányában - fellebbezésnek van helye,

fb) a jogeröre emelkedést követöen a Be. 649. § (1)-(2) és (6) bekezdése szerinti felülvizsgálati indítvány nem terjeszthetö elö,

fc) a jogeröre emelkedést követöen a Be. szerinti törvényesség érdekében bejelentett jogorvoslat nyújtható be $[\ldots]^{39}$

(6) ${ }^{40}$ Ha e törvény, vagy más törvény eltéröen nem rendelkezik, a büntetésvégrehajtási bíró eljárására a büntetőeljárás szabályait kell alkalmazni azzal, hogy bizonyitási indítvány elöterjesztésére vonatkozóan a Be. 520. \& nem alkalmazható és elökészitö ülés megtartásának nincs helye."

Rögtön ellentmondásként értelmezhető a Bv.tv. 50. (1) bekezdés f) pont és fa) alpontjában foglaltak és a Be. 456.§ (1) bekezdés 2 . mondatában foglaltak között. Ugyanis előbbi szerint a bv. bíró ügydöntő végzése ellen fellebbezésnek van helye, míg utóbbi - Be. szerinti - szabály szerint az ügydöntő határozat a jogeröre emelkedését követően kizárólag rendkívüli jogorvoslattal vagy különleges eljárás eredményeként változtatható meg. Az ellentmondást az ügydöntő szó használatán vélem tetten érhetőnek, hiszen a Be. egyértelművé teszi, hogy milyen határozatot tekinthetünk ügydöntőnek, és ez nem mondható el a bv. bíró végzéséről.

További beszédesnek mondható ellentmondást fedezhetünk fel a fenti, (6) bekezdéshez füzött indokolásban is, amely szerint:

"[...] [A] bv. bírói eljárás tárgya nem a büntetöjogi felelösség, a tárgyalás tartását egyes tényeket, körülményeket érintö bizonyitás felvétele indokolja, ezért a klasszikus büntetöeljárást szolgáló szabályok szükségtelenek, azok kizárását az egyértelmüség érdekében jogszabályi szinten kell kimondani."

Tehát itt rögtön felvetődik az a kérdés, hogy ha a büntetőeljárást szolgáló szabályok "szükségtelenek"(!), akkor azokat miért kell a bv. bírói eljárásokban háttérjogszabályként alkalmazni?!

A törvényesség érdekében bejelentett jogorvoslatra ${ }^{41}$ később részleteiben is kitérek, elöljáróban azonban - összefüggésben a Bv.tv. 50.§ (1) bekezdésével - ki kell emelni, hogy maga (Be.-ben a rendkívüli jogorvoslatok között szabályozott) a jogintézmény már a 2017. november 13. napján kihirdetett, a büntetőeljárásról szóló

${ }^{39} \mathrm{Az}$ fb) és fc) pontok módosítása a 2020. május 29. napján kihirdetett, a büntetőeljárásról szóló törvény és más kapcsolódó törvények módosításáról szóló 2020. évi XLIII. törvény 91. § (1) bekezdése szerint - 2021. január 1. napi hatályba lépéssel történt meg.

40 Beiktatta: a büntetőeljárásról szóló 2017. évi XC. törvény hatálybalépésével összefüggő egyes törvények módosításáról szóló, 2017. december 19. napján kihirdetett 2017. évi CXCVII. törvény 474.§ 51. pontja

${ }^{41} A$ törvényesség érdekében bejelentett jogorvoslatot az 1999. évi CX. törvény 94 . §-a vezette be az 1973. évi I. törvénybe. A miniszteri indokolás szerint azért, mert a gyakorlat azt mutatta, hogy előfordulnak olyan - súlyos - jogsértések, amelyek nem más módon kiküszöbölhetők. (Lichtenstein: i.m.; Belovics Ervin: A rendkívüli jogorvoslatok. In: Büntető eljárásjog. Harmadik, aktualizált kiadás. $A z$ új 2017. évi büntetőeljárási törvény tankönyve. (szerk.: Belovics Ervin - Tóth Mihály), Budapet, HVGORAC Lap- és Könyvkiadó Kft., 2017, 549. o.) 
1998. évi XIX. törvény, egyes büntető tárgyú törvények, valamint az európai uniós és a nemzetközi bűnügyi együttműködést szabályozó törvények módosításáról szóló 2017. évi CXLIV. törvény 94.§-a alapján 2018. január 1. napi hatállyal bevezetésre került a büntetés-végrehajtási törvénybe akként, hogy a Bv.tv. 51. § (5) bekezdése helyébe a következő rendelkezés lépett:

„(5) A büntetés-végrehajtási bíró és a törvényszék másodfokú határozatával szemben a Be. szerinti törvényesség érdekében bejelentett jogorvoslat alapján a Kúria a törvénysértés megállapítása esetén a megtámadott határozatot

a) megváltoztathatja, vagy

b) hatályon kívül helyezheti, és az eljárást megszüntetheti, vagy szükség esetén az eljárt biróságot

új eljárásra utasithatja."

Ennek megfelelően pedig szükségtelennek volt értékelhető az, hogy a 2020. évi XLIII. törvény 91 . § (1) bekezdése szerint - 2021. január 1. napi hatályba lépéssel - a Bv. tv. 50. § (1) bekezdése a fentebb írt fc) ponttal úgy egészült ki, hogy ráadásul az a törvényesség érdekében bejelentett jogorvoslathoz fúződően külön kielemi a jogeröre emelkedést. Mindezt annak ellenére teszi, hogy a Be. 667. §-ához füzött kommentár szerint , $[\mathrm{A}]$ törvényesség érdekében jogorvoslatnak a bíróság törvénysértő jogerős ügydöntő határozata és végleges nem ügydöntő végzése ellen egyaránt helye lehet."

A bv. bírói határozatok jogerejével, ügydöntő jellegével, avagy véglegessé válásra "képes" jellegével összefüggésben a jogalkalmazásban tapasztalt eltérések kiküszöbölése érdekében először a Kúria Bfv.II.1.326/2018.szám alatti döntés elvi tartalmának összefoglalása a következőket szögezte le:

1. A véglegessé vált bv. bírói ügydöntő végzés ellen utólagos bv. bírói eljárásnak, míg az utólagos bv. bírói eljárásban hozott véglegessé vált bv. bírói ügydöntő végzés ellen ugyancsak utólagos bv. bírói eljárásnak van helye.

2. A bv. biró véglegessé vált ügydöntő végzése nem jogerös határozat. Azzal szemben felülvizsgálatnak nincs helye.

A Kúria arra az álláspontra helyezkedett, hogy: „[A]mennyiben az érdemi, azaz ügydöntö végzés ellen nem jelentettek be fellebbezést vagy a bejelentett fellebbezést a törvényszék másodfokú tanácsa érdemben elbirálja, akkor a meghozott elsöfokú és másodfokú ügydöntö végzés nem jogerössé, hanem követve a büntetöeljárási terminológiát - véglegessé válik. $A$ véglegessé vált bv. birói ügydöntö végzés ellen utólagos bv. birrói eljárásnak van helye."

Indokolásképp a Be. vonatkozó, azon szabályára utalt vissza, mely szerint a bíróság jogerős ügydöntő határozata végleges, mindenkire kötelező döntést tartalmaz a vádról, illetve a terhelt büntetőjogi felelősségéről, a büntetőjogi következményekről vagy ezek hiányáról [Be. 456. § (1) bekezdés 1. mondat]. Erre tekintettel állapította meg azt, hogy "[A] bv. bíró véglegessé váló érdemi (és a törvény kötelezö terminológiája szerint ügydöntö) határozata azonban jogeröre nem képes, mert nem a vádról, illetve nem a terhelt büntetöjogi felelösségéröl, a büntetöjogi következményekröl vagy ezek hiányáról tartalmaz döntést. Ily módon a 
bv. bíró véglegessé váló ügydöntö határozata nem jogerős határozat, s így azzal szemben a büntetőeljárási törvény alapján is kizárt a felülvizsgálat."

Úgy vélem, hogy ezen határozat fényében került kialakításra - tudomásom szerint - a legtöbb törvényszék büntetés-végrehajtási csoportjában az a gyakorlat, hogy a bv. bírói eljárás során hozott határozatokat nem jogerősítési, hanem véglegessé válási záradékkal látják el.

A BH2020. 360. szám alatt megjelent, a Kúria Bfv. I. 573/2020. szám alatti döntésének elvi tartalmának összefoglalása szerint pedig: A büntetés-végrehajtási bírónak az alapvető jogokat sértő elhelyezési körülmények miatti kártalanítási igény tárgyában hozott kártalanitást megállapitó végzése ügydöntö, de nem jogerös birósági határozat, ezért ellene felülvizsgálatnak nincs helye. Lehetőség van azonban utólagos bv. bírói eljárásra, ha az előző kérdésben nem a törvénynek megfelelően rendelkezett [2013. évi CCXL. tv. 10/A. § (1) bek., 50. § (1) bek. f) pont fa) és fb) alpont, h) pont 2. ford., 52-75. §, 71. § (1) bek., 75/A. §; 3087/2020. (IV. 23.) AB határozat [38]].

$\mathrm{Az}$ elvi tartalom lényege ugyanazon értelmezést követi, mint a fentebb hivatkozott, előző"2 határozat. Ugyanakkor - és a „problémát" ez adja - ezen lényegi következtetés ellentétben áll a határozat indokolásában foglaltakkal és a Kúria által is hivatkozott alkotmánybírósági határozatban foglaltakkal is. Az indokolási rész [8] pontja ugyanis már azt írja, hogy „[A] Bv.tv. 52-75/A. §-a szerinti bv. bírói eljárások, így pl. a kártalanitás tárgyában érdemben (alapvetően: kártalanítást megállapító, vagy azt elutasító) hozott határozat tehát jogeröképes ügydöntő végzés (anyagi jogerö). A nem érdemben hozott határozatok pedig nem jogeröre emelkednek, hanem véglegessé válnak (alaki jogerő)."

További indokolási részében a határozat ugyanúgy a Be. vonatkozó szabályában foglaltak részletes elemzésével igyekszik alátámasztani az ily módon kissé nehezen követhető döntés lényegi következtetését.

Kiemelésre kerül, hogy a kártalanítás tárgyában érdemben hozott egyébiránt jogerös ügydöntő végzés mégsem azonos a perbíróságnak büntetőügyben a vád tárgyában hozott jogerős ügydöntő határozatával. Megismétli a korábbi határozatban foglaltakkal egyezően, hogy a bíróság jogerős ügydöntő határozata ugyanis végleges, mindenkire kötelező döntést tartalmaz a vádról, illetve a terhelt büntetőjogi felelősségéről, a büntetőjogi következményekről vagy ezek hiányáról [Be. 456. § (1) bek. 1. mondat]. Ez a rendelkezés lényegében megegyezik a korábbi büntetőeljárási törvény szabályával, amely kimondta, hogy a bíróságnak az ügydöntő határozatban a vádról kell határoznia [a büntetőeljárásról szóló 1998. évi XIX. tv. (a korábbi Be.) 257. § (1) bek. 2. mondat]. A Kúria szerint a lényegében azonos szabályozásra figyelemmel nincs ok változtatni azon a következetes ítélkezési gyakorlaton, amely szerint ügydöntőnek azok a határozatok tekintendők, amelyekben a bíróság a Be. vonatkozó szabályai szerint lefolytatott bírósági eljárást követően a vádról határoz, az ügy érdemében hoz mindenkivel szemben kötelező érvényü, a terhelt büntetőjogi felelősségét megállapító, vagy őt felmentő itéletet, illetve eljárást megszüntető végzést (EBH2004. 1016).

\footnotetext{
${ }^{42}$ Kúria Bfv.II.1.326/2018.szám alatti döntés
} 
Leszögezte a testület, hogy a Bv.tv. 52-75/A. §-a szerinti - így pl. a kártalanítás tárgyú bv. bírói eljárások egyfelöl nem büntetőügyek, hanem bv. ügyek [Bv.tv. 3. § 1. pont], másfelől annak során nem a vádról, hanem valamely bv. ügyről döntenek. Ugyanakkor mégis fenntartotta azon következtetését, hogy jogerős ügydöntő határozat "jellegű́ek" azon határozatok, amelyekben a bv. bíró a kártalanítási eljárás során érdemben megállapító rendelkezést hoz - és ezzel összefüggésben az utólagos bv. bírói eljárással kapcsolatosan kimondja: „[M]indennek megfelelően a bv. bíró a Bv.tv. 52-75/A. §-a szerinti eljárásokban érdemben hozott jogerös ügydöntö- jelen esetben kártalanítást megállapító - végzését utólag maga korrigálhatja, ha arról nem a törvénynek megfelelöen rendelkezett."

$A z$ indokolási részben a Kúria által is hivatkozott 3087/2020. (IV. 23.) $A B$ határozat [38] bekezdése a következőket írja:

"[A] Bv. tv. 50. \& (1) bekezdés f) pontjában foglalt szabály 2018. július 1-jén lépett hatályba, annak szövegét a büntetőeljárásról szóló 2017. évi XC. törvény hatálybalépésével összefüggő egyes törvények módositásáról szóló 2017. évi CXCVII. törvény 430. \& (1) bekezdése állapította meg. A módositó törvény javaslatának az elóterjesztói indokolása szerint a bv. bíró döntése, akárcsak a büntetöügyben eljáró perbíróé, tartalmi szempontból kétféle lehet. Abban az esetben, ha a döntés az alapügyben eljáró bíró itéleti rendelkezését érinti, érdemi jelentőségü (pl. fokozatváltás, feltételes szabadságra bocsátás lehetőségének kizárása), ez esetben végzése ügydöntö, míg nem ügydöntö, ha felülbiráló fórumként jár el (bírósági felülvizsgálati eljárás) vagy a határozat valamely eljárási cselekményhez kötödik (halasztás engedélyezése, elövezetési költség megállapitása vagy rendbirság kiszabása). A módositás tehát a Be. bírói döntésekben kialakított rendszerének való megfeleltetést valósítja meg azzal az elöirással, hogy a bv. biró végzését jogeröképes ügydöntö végzésnek minösíti a bv. bírói eljárásokban, míg azon kívüli esetekben a bv. biró végzése - akár a peres biróé, ha nem a büntetójogi felelösségröl vagy jogkövetkezményröl határoz - nem ügydöntő és véglegessé válik."

A kérdés - vagyis, hogy a bv. bírói határozatokat akkor jogerősítési vagy véglegessé válási záradékkal kell ellátni - elsőre marginálisnak tűnhet. Ugyanakkor a kérdéskör súlyát szemlélteti, hogy az Alkotmánybíróság a fenti értelmezés alapján, azt összevetve az Alaptörvényben foglalt bírósághoz való fordulás jogával és a jogdogmatika szerint kidolgozott elvekkel - pl. anyagi/alaki jogerő, res iudicata (ítélt dolog), ne bis in idem, stb. - a konkrét ügyben úgy határozott, hogy törvényszéki első- és másodfokú határozatokat megsemmisít ${ }^{43}$.

\footnotetext{
43 Juhász Imre alkotmánybíró párhuzamos indokolása is szemléletes: „[A]z Alkotmánybíróságnak a jelen ügyben tehát pusztán arról kellett döntenie, hogy a rendes bíróságok helyesen értelmezték-e az anyagi és alaki jogerö fogalmát, illetve helyesen döntöttek-e, amikor "itélt dolognak" minősi-tették a korábbi eljárásban hozott, a kérelmet formális okból elutasitó végzést, ezzel elvonva a kártalanítás vitatásának lehetöségét az érintett időszakot illetően. $A$ bíróságok egyértelmüen félreértelmezték az anyagi jog-eró fogalmát, amikor az alaki jogerőt egyúttal anyagi jogerőként kezelték, figyelmen kívül hagyva, hogy ezzel elzárták az indítványozót a bírósághoz fordulás jogától, és így a felvetett kérdés érdemi megválaszolásának lehetőségétől.
} 
Az ellentmondások sorának folytatásaképp - visszatérve - ismét fel kell említeni a törvényesség érdekében bejelentet jogorvoslat Bv.tv. szerinti szabályozását és annak mögöttes elgondolásait.

Előtte azonban egy kisebb kitérőt téve szeretném megjegyezni, hogy magának a jogintézménynek külön érdekessége, a Be.-ben a rendkívüli jogorvoslatok között szerepel, amelyekről a jogdogmatika azt munkálta ki, hogy azok jogerős bírósági határozatokkal szemben vehetők igénybe. A Be. kommentár szerint:

"[A]z anyagi igazság érvényesülésére éppúgy nem biztosít (nem biztosithat) alanyi jogot a jogrend, mint ahogy arra sem, hogy egyetlen birósági ítélet se legyen törvénysértö. $A z$ igazságos és törvényes bírósági döntés érdekében azonban további eljárási garanciát tartalmaz az Alkotmány: alkotmányos jogot a jogorvoslathoz [9/1992. (I. 30.) AB határozat indokolás V.4. pont]. A jogorvoslathoz való jog azonban csak a rendes jogorvoslatra vonatkozik. Így az alkotmányos követelményt kielégíti az a szabályozás, amely az adott bírói (hatósági) döntés ellen a jogorvoslatot fellebbezés (rendes perorvoslat) útján lehetóvé teszi [1320/B/1993. AB határozat indokolás II.4.].

Mindez azonban nem jelenti azt, hogy megengedhetö volna egy olyan szabályozás, mely a jogerös határozatok semmiféle korrekcióját nem tenné lehetövé. Más alkotmányos elvekböl, értékekböl - igy a jogbiztonság követelményéböl - egyértelmüen fakad a rendkívüli jogorvoslatok létének szüksége. Elöfordulhat - miként azt Finkey Ferenc: A törvénysértés fogalma a büntetó jogegységi perorvoslatban (Magyar Jogi Szemle Könyvtára. Budapest, 1924,4 . o.) címú írásában is kifejtette - "[...], hogy [...] oly súlyosabb természetü kisiklás, elnézés, félreértés vagy helytelen jogi felfogás érvényesült egy jogerös itéletben vagy intézkedésben, melyet a jog uralmának, a törvény szentségének elve, az igazságszolgáltatás magasztos szempontjából elhallgatni, helyreigazitás nélkül eltürni nem szabad [...]." Az ilyen tolerálhatatlan hibák orvoslásának lehetöségét indokolt a jogrendszeren belül megteremteni."

"Ugyanakkor a jogerōs határozatok megváltoztathatatlanságához és irányadó voltához alapvetố alkotmányos érdek füződik. A jogállamiság lényeges eleme, hogy a törvénynek egyértelmüen meg kell határoznia, mikor támadható meg egy birósági határozat rendes fellebbviteli jogorvoslattal, illetve, hogy a jogerössé vált határozat megtámadására milyen feltételek alapján van lehetöség, $s$ hogy mikor következik be az az állapot, amikor a jogerös határozat már semmiféle jogorvoslattal nem támadható [9/1992. (I. 30.) AB határozat indokolás V.4. pont]. A Be. ezen alapelvekre tekintettel rendezi a rendkivüli jogorvoslatok rendszerét. Annak formái a következök: perújitás; felülvizsgálati eljárás; az alkotmányjogi panasz; jogorvoslat a törvényesség érdekében; a jogegységi eljárás és az egyszerüsitett felülvizsgálat."

A Bv.tv. 50.§ (1) bekezdés fc) pont szerinti megfogalmazás szintén - fentiek fényében különösen - érdekes, hiszen abból kiindulva arra vonhatnánk le következtetést, hogy a bv. bíró véglegessé váló határozatival szemben ezen rendkívüli jogorvoslat kimerítése nem lehetséges, mert kifejezetten jogerőről 
rendelkezik a jogalkotó, holott $51 . \S(5)$ bekezdése sem rendelkezik külön jogerőről vagy véglegességről, továbbá ügydöntő jellegről sem.

A Bv.tv. fenti jogszabályhelyéhez füzött indokolás szerint a Be. 431. §-a (régi Be.) nevesíti tartalmi szempontból azokat a határozatokat, melyet a Kúria a törvényesség érdekében bejelentett jogorvoslat alapján meghozhat. Ez a rendelkezés nem vonatkozhat olyan eljárásra, ahol a Kúria bv. bírói határozatot vizsgál meg, hiszen a büntetés-végrehajtási bírói végzése nem érinti a büntetőjogi felelősséget, és szankció kiszabásáról sem rendelkezik. Erre tekintettel szükséges külön szerepeltetni a Bv.tv.-ben azokat a határozatokat, amelyeket a Kúria meghozhat, ha a törvényesség érdekében bejelentett jogorvoslat tárgya büntetés-végrehajtási bíró végzése, melyek közé a módosítás iktatja be az eljárás megszüntetésének lehetőségét.

A Be. 669. §-ához füzött kommentár így fogalmaz: „[A] Bv.tv. 51. § (5) bekezdésében meghatározott különleges esetben a Kúria a büntetés-végrehajtási bíró és a törvényszék másodfokú határozatával szemben a törvényesség érdekében bejelentett jogorvoslat alapján, a törvénysértés megállapítása esetén a megtámadott határozatot egyrészt megváltoztathatja, másrészt hatályon kívül helyezheti, és az eljárást megszüntetheti, vagy szükség esetén az eljárt bíróságot új eljárásra utasíthatja. A büntetés-végrehajtási bírói határozatokra vonatkozó eltérő rendelkezések oka az, hogy a büntetés-végrehajtási bíró végzése nem érinti a büntetőjogi felelősséget, és szankció kiszabásáról sem rendelkezik."

A Be. 667.§ (1) bekezdése szerint ugyanakkor a legfőbb ügyész a törvényesség érdekében jogorvoslatot jelenthet be a bíróság törvénysértő jogerős ügydöntő határozata és végleges nem ügydöntő végzése ellen. Ezt támasztja alá a szakaszhoz rendelt kommentár is, amely szerint pedig: „[A] törvényesség érdekében jogorvoslatnak a bíróság törvénysértő jogerős ügydöntő határozata és végleges nem ügydöntő végzése ellen egyaránt helye lehet. [...] A jogorvoslat egy különleges esetére utal a Bv.tv. 51. § (5) bekezdése, amely alapján a rendkívüli jogorvoslat tárgya lehet a büntetés-végrehajtási bíró és a törvényszék másodfokú határozata is." 44

A BH2020. 103. II. pontja is külön utal ${ }^{45}$ a 70/A. § (5) bekezdésére - az érdemi vizsgálat nélküli elutasítási okokat részletezi -, ami alapján hozott határozatok nem ügydöntőek, ennek megfelelően jogerőre nem képesek, véglegessé válnak. A Be.

\footnotetext{
${ }^{44}$ Ezzel összefüggésben egy további "nehézségre" is rávilágítok: a törvényesség érdekében bejelentett jogorvoslati eljárás megindítása nem zárja ki azt, hogy ezzel párhuzamosan az Alkotmánybíróság előtt alkotmányjogi panaszeljárás keretében is "felülbírálatra" kerüljön egy ügy. Ezzel kapcsolatban akkor adódhat feloldhatatlannak tűnő helyzet, ha a Kúria a törvényesség érdekében bejelentett jogorvoslat folytán nem helyezi hatályon kívül az érintett határozatot, hanem a törvényeknek megfelelő határozatot hoz, miközben az Alkotmánybíróság esetleges Alaptörvény-ellenesség okén a támadott bírói döntést megsemmisíti.

Még tovább is bonyolódhat a kérdéskör, ha figyelembe vesszük azt is, hogy a Bv.tv. 71.§-a szerint akár maga a bv. bíró is, - akár hivatalból (!) - a (3) bekezdés szerint, ha a határozatában nem a törvénynek megfelelően rendelkezett, a határozatot hatályon kívül helyezheti és a törvénynek megfelelő határozatot hozhat.

45 Megjegyzem, hogy a Kúria külön ki is javította az alábbiak szerint az alsóbb fokú bíróságok záradékolását is (BH2020. 103. [2]): „[A] másodfokú bíróság a végzés záradékában megállapította, hogy az elsőfokú végzés a másodfokú végzéssel aznap jogerős (helyesen: véglegessé vált)."
} 
kommentár ${ }^{46}$ szerint ugyanakkor az érdemi vizsgálat nélküli elutasító, nem érdemi határozatokkal szemben is igénybe vehető a törvényesség érdekében bejelentett jogorvoslat. Hivatkozni kell arra is, hogy a polgári perjog ilyen különbségtételt nem tesz. Szükségesnek tartom hivatkozni a polgári perjogban megalkotott fogalmi meghatározásra is - mivel az sok tekintetben felhasználható a büntetőeljárásban is. ${ }^{47}$ Farkas József meghatározása szerint a polgári perjogban a jogerőn a bírósági határozatoknak azt a tulajdonságát kell érteni, hogy rendes fellebbviteli perorvoslattal nem támadhatók már meg, illetőleg nem vagy csak korlátozottan változtathatók meg, és a bírósági határozatnak ehhez az állapotához - és pedig nem a jogerős határozat valamelyik részéhez, hanem az ügy érdemében hozott döntéshez - különféle hatások füződnek. Ezeket „jogerőhatásoknak" nevezi, lényege, hogy a jogerősen eldöntött kérdés irányadóvá válik mind a felekre, mind a később eljáró bíróságokra (esetleg más hatóságokra). Tehát Farkas szerint a jogerőhatás a jogerős döntés irányadó voltában, az ahhoz füződő kötöttségben áll, a jogerő hatása (anyagi jogereje) egyrészt a vita végleges eldöntését jelenti, másrészt pedig a minősített kötőerőt a bíróság (és más hatóság) felé. ${ }^{48}$

A polgári eljárásjogi dogmatika szerint is tehát a bírósági határozatoknak célja, hogy a peres felek egymás közötti viszonyában valamilyen joghatást idézzen elö, így a határozatok két legfontosabb, legmarkánsabb joghatása a kötőerő ${ }^{49}$ és a jogerő. ${ }^{50}$ "[A] jogerő az a joghatás, melynél fogva a bírósági határozat megtámadhatatlanná, véglegessé és végrehajthatóvá válik." ${ }^{51}$

A Pp. az alaki jogeró kifejezést sehol nem tartalmazza, a határozat megtámadhatatlanságát jelenti, azaz azt, hogy a határozat fellebbezéssel, ellentmondással többé nem támadható meg. ${ }^{52}$ Ezt írja a Pp. 358.§ [A jogerő] (1) bekezdése tulajdonképpen, amikor arról rendelkezik, hogy a határozat a jogeröre emelkedését követően nem támadható meg fellebbezéssel. Az anyagi jogerőt is pontosan meghatározza a jogszabály. A Pp. 360.§ [Az anyagi jogerőhatás] (1) bekezdése szerint a keresettel és az ellenkövetelés fennállta tekintetében érdemben elbírált beszámítással érvényesített jog tárgyában hozott ítélet jogereje kizárja, hogy ugyanabból a tényalapból származó ugyanazon jog iránt ugyanazok a felek - ideértve azok jogutódait is - egymás ellen új keresetet indíthassanak, vagy az ítéletben már elbírált jogot egymással szemben egyébként vitássá tehessék.

A Pp. 176. § [visszautasítás] (1) bekezdés d) pontja szerint a bíróság hiánypótlási felhívás kiadását mellőzve - a keresetlevelet visszautasítja, ha a felek között ugyanabból a ténybeli alapból származó ugyanazon jog iránt indított más

\footnotetext{
${ }^{46}$ Kommentár a büntetőeljárásról szóló 2017. évi CX. törvényhez - Főszerkesztő: Polt Péter

${ }^{47}$ Elek: i.m. 75.

${ }^{48}$ Farkas József: A jogerő a magyar polgári peres eljárásban. Budapest, Akadémiai Kiadó, 1976, 23. o.

49 A Pp. 357. § (1) bekezdése szabályozza az egyszerü kötőerőt, mely szerint: e törvény eltérő rendelkezése hiányában a bíróság a saját határozatához abban a perben, amelyben azt hozta a határozat kihirdetésétől, ennek hiányában a közlésétől kezdve kötve van.A Bv.tv.-ben ez a kötőerő oldható fel tulajdonképpen az utólagos bv. bírói eljárás keretében.

50 Völcsey Balázs: A jogerőhatás megjelenési formái. Themis - ELTE-ÁJK Doktori Iskola elektronikus folyóirata, 2014. december, 367-385., 367. o.

${ }^{51}$ BH2002. 462.

52 Völcsey: i.m. 372. o.
} 
perben a perindítás joghatása már beált vagy annak tárgyát már jogerōsen elbirálták. Az ehhez füződő hatások "feloldhatóságát" rögzíti ugyanakkor 178. § [a keresetlevél előterjesztéséhez füződő joghatások fenntartása] (1) bekezdése amely kimondja, hogy a keresetlevél visszautasítása esetén a keresetlevél előterjesztésének joghatásai fennmaradnak, ha a felperes az ügy előzményére hivatkozással, a visszautasító végzés jogerőre emelkedésétől számított harminc nap alatt a keresetlevelet szabályszerüen - a már megfelelően becsatolt mellékletek kivételével - újra előterjeszti, vagy igényét egyéb úton szabályszerűen érvényesíti. A határidő elmulasztása esetén igazolásnak nincs helye.

Azért tartottam fontosabb a polgári perjogi szabályok becitálását, mert az alapvető jogokat sértő elhelyezési körülmények miatti, Bv. tv. szerinti kártalanítás alapvető jellegét illetően hasonlóságot mutat az annak bevezetését megelőző polgári perekkel - kis túlzással a bv. kártalanítások részben "a polgári jog talaján állnak". Ugyanis amíg a Bv.tv.-be nem került bevezetésre a kártalanítás, az elítéltek és egyéb jogcímen fogvatartottak polgári peres úton érvényesíthették emberi méltóságukban bekövetkezett sérelmeiket a bv. intézetekkel szemben. A polgári perekben született határozatokban pedig a bíróságok - amennyiben megállapították a felperes személyiségi jogainak megsértését - ugyanúgy, mint a bv. kártalanítási eljárásokban született bv. bírói határozatok, fizetésre kötelezték a másik felet (polgári perben a bv. intézet, a bv. bírók pedig magát az államot). Mindkét eljárásnak a lényegi következménye tehát ugyanaz: a jogsértő félnek fizetési kötelezettsége keletkezik a jogsértést elszenvedővel szemben. Ennek megfelelően tehát alapvetően nem látom indokát annak, hogy magát az anyagi jogerőnek az intézményét és az ahhoz füződő hatásokat eltérően kelljen értelmezni a polgári peres eljárásokban és a bv. bírók előtti kártalanítási eljárásokban.

Elegendő, ha csupán a jogbiztonságra gondolunk. A bv. bírói kártalanítások kapcsán a fizetésre kötelezett az állam, a kifizetést az Igazságügyi Minisztériumnak kell teljesíteni. Ugyanakkor a határozat tartalmazhat kötelező erejü rendelkezést annak kapcsán is, hogy a kérelmező (elítélt vagy egyéb jogcímen fogvatartott) részére megállapított kártalanításból a büntetőeljárásban magánfélként polgári jogi igényüket érvényesítő sértettek felé is kifizetést kell teljesíteni. Ha még tovább vesszük az „érintettek" körét, akkor számba kell venni esetleg azt is, hogy meg kell keresni a Magyar Bírósági Végrehajtó Kart, tisztázni kell, hogy van -e esetleg gyermektartásdíj-követelés az elítélttel szemben, szükségessé válhat az állami adóés vámhatóság megkeresése is, stb. ${ }^{53}$

Szemmel látható tehát, hogy egy alapvető jogokat sértő elhelyezési körülmények miatti kártalanítási igény érdemi elbírálását követően mennyi további („közvetett”) érintett lehet ebből a jogviszonyból kifolyólag és ha a határozathoz nem kapcsoljuk az anyagi jogerőhöz fúzött hatásokat, akkor az olyan komoly bizonytalansági tényező lehet álláspontom szerint, ami a jogbiztonságot veszélyezteti. Visszautalok a 2/2015. Büntető Jogegységi Határozatra, melynek egyik lényegi következtetése, hogy ítélt dolgot csak az anyagi jogerő keletkeztet. A kártalanítást érdemben elbíráló határozatokhoz mindenképp szükséges véleményem szerint, hogy ez az ítélt dolog

\footnotetext{
${ }^{53}$ A bv. kártalanításokkal kapcsolatos kifizetési szabályokat lásd részletesen: Bv.tv. 75/O.§ - 75/S.§
} 
hatás kapcsolódjon (utóbb ne lehessen vitássá tenni). Azonban ennek eredményeképp úgy kellene tekinteni ezen határozatokat, mint amelyek ügydöntőek is - ez ugyanakkor a jelenlegi Be. megfogalmazásával nehezen hozható összhangba ${ }^{54}$.

Hasonló konklúziót vont le korábban - szintén kártalanítási ügyben - az Alkotmánybíróság a 3335/2019. (XII.6.) AB határozat [37] bekezdésében:

"[...] [e] speciális büntetés-végrehajtási eljárásban az a döntés minősül érdemi döntésnek, amelyik kimeríti a kérelmet, tehát a fogvatartás körülményeit megvizsgálva, értékelve rendelkezik arról, hogy fennáll-e a kártalanitás jogalapja (alapvetö jogokat sértő elhelyezési körülmények fennállásnak a feltétele), illetve igenlö válasz esetén az összegszerüségröl is rendelkezik. Ezzel összhangban a Bvtv. ismertetett - érdemi vizsgálat nélküli elutasítást lehetövé tevö - rendelkezései alapján rögzithetö, hogy a felsorolt esetekben a büntetés-végrehajtási bíró a kérelmet nem meríti ki, annak érdemi vizsgálatába nem bocsátkozik, mert olyan feltétel meglétének a fennállását állapítja meg, ami akadályát képezi az érdemi vizsgálatnak és döntésnek."

A bv. kártalanítások kapcsán álláspontom szerint tehát ugyanakkor azokat a határozatokat nem lenne célszerü jogerővel „felruházni" - mint ahogy erre az Alkotmánybíróság is utalt -, amelyekben a kérelem érdemi vizsgálat nélküli elutasításra kerül sor, hiszen, ha ezek a határozatok anyagi jogerő-hatással bírnának, az kizárná a bírósághoz újbóli fordulás jogát, amely Alaptörvény-ellenes ${ }^{55}$ Ebben az esetben tehát továbbra is a véglegessé válási záradékkel történő ellátást tartom indokoltnak.Ezt támasztotta alá az Alkotmánybíróság is a 3087/2020. (IV. 23.) AB határozat [55]-[56] bekezdésében:

[Í]gy, a Bv. tv. 50. \& (1) bekezdés f) pontja és Bv. tv. a 70/A. \& (5) bekezdés c) pontja szerinti rendelkezések együttes értelmezéséböl egyértelmüen következik, hogy a bv. bíró azon végzése, amely a kártalanítási kérelem érdemi vizsgálat nélküli elutasításáról szól, nem minősül ügydöntö végzésnek. A fentiekre figyelemmel továbbá, vagyis mivel a Be. rendelkezései értelmében csak az ügydöntö határozatok képesek anyagi jogeröre és keletkeztetnek ítélt dolgot, a kártalanítási kérelmet érdemi vizsgálat nélküli elutasitó végzés csupán alaki jogeröre képes. Ennek megfelelöen itélt dolgot sem keletkeztet." További kérdésként feltehetjük azonban azt az esetkört, amikor a kártalanítási kérelem kapcsán olyan határozatot hoz a bv. bíró (vagy titkár), hogy a kérelem egy részét érdemben elbírálva, annak helyt ad és az államot kártalanítás megfizetésére kötelezi, viszont egy másik részét (a kérelemeztt időszak egy részét illetően) érdemi vizsgálat nélkül elutasítja. Kétféle záradékkal (jogerősítési és véglegessé válási) ugyanis nem lehet ellátni a határozatokat, azt nem lehet kimondani, hogy a határozat egy része jogerős, másik része pedig véglegessé vált.

\footnotetext{
${ }^{54}$ Ezen utóbbi megállapítással az Alkotmánybíróság ellentétes álláspontra helyezkedett.

55 lásd 3087/2020. (IV.23.) AB határozat [52]: „[M]indebből az Alkotmánybíróság szerint az következik, hogy az „ítélt dolog" mint eljárási akadály alkotmányos érvényesülésének alapvető feltétele, hogy az adott döntés érdemi vizsgálat eredményeként szülessen meg. Az e kritériumnak nem megfelelő döntések res iudicata-ban megnyilvánuló eljárási akadályként való - téves - értékelése pedig az Alaptörvény érvényesülése ellen hat, hiszen a bírósághoz fordulás jogát akadályozza \{3335/2019. (XII .6.) AB határozat, Indokolás [24]-[25]\}."
} 
Bár e körben meg kell jegyeznem azt is, hogy a Bv.tv. 75/F. $\S(1)$ bekezdés f) pontja szerint a bv. intézet a kérelmet visszautasítja, ha a kérelemben kifogásolt időszak tekintetében a bv. intézet korábban a kérelem egyszerűsített elbírálásáról döntött vagy a büntetés-végrehajtási bíró kártalanítást ítélt meg. Ugyanilyen - „bv. bírói szakban" érdemi vizsgálat nélküli elutasítási -okot részletez a jogszabály a bv. bíró előtti kártalanítás iránt indult eljárásokban is a 75/L. § fa) pontja. ${ }^{56}$

Bár még a teljesség érdekében meg kell jegyezni azt is, hogy az Alkotmánybíróság értelmezése szerint teljesen egyértelmű válasz adható arra a kérdésre, hogy mikor tekinthető jogerőre képesnek és mikor "csupán" véglegessé válónak a bv. bíró határozata. A korábban már idézett 3087/2020. (IV. 23.) AB határozat Indokolásának [38] bekezdése szerint ugyanis a Bv.tv. hatályos szövege a Be. bírói döntésekben kialakított rendszerrel összhangban áll, amikor a bv. bíró végzését jogerőképes ügydöntő végzésnek minősíti a bv. bírói eljárásokban, míg azon kívüli esetekben a bv. bíró végzése - akár a peres bíróé, ha nem a büntetőjogi felelősségről vagy jogkövetkezményről határoz - nem ügydöntő és véglegessé válik. Ugyanakkor pontosan a kártalanítási eljárással összefüggésben tartom támadhatónak az Alkotmánybíróság érvelését is, hiszen annak során véleményem szerint nem büntetőjogi felelősségről vagy annak jogkövetkezményéről határoz a bv. bíró. Úgy vélem, hogy az, hogy milyen elhelyezési körülményeket biztosítanak a hazai büntetés-végrehajtási intézetek az elítélteknek és ezáltal sérülnek -e az alapvető jogaik, nem abból következik, hogy egy elítéltnek a büntetőjogi felelősségét megállapította a büntető bíróság (perbíróság). Megfordítva ezt úgy is megfogalmazhatjuk, hogy a büntetőjogi elítélésnek nem feltétlenül következménye az, hogy alapvető jogokat sértő elhelyezési körülmények közé kerül egy elítélt, akinek ezáltal megnyílik a „jogosultsága" arra, hogy ez alapján kártalanítási igénnyel lépjen fel az állammal szemben.

Ugyanakkor a hivatkozott Alkotmánybírósági indokolás többi részében foglaltakkal egyet tudok érteni, amely szerint akkor, ha a bv. bírói döntés az alapügyben eljáró bíró ítéleti rendelkezését érinti, érdemi jelentőségű (pl. fokozatváltás, feltételes szabadságra bocsátás lehetőségének kizárása), ekkor végzése ügydöntő, míg nem ügydöntő, ha felülbíráló fórumként jár el (bírósági felülvizsgálati eljárás) vagy a határozat valamely eljárási cselekményhez kötődik (pl. elővezetési költség megállapítása).

Végezetül utalni kell arra is, hogy a jogalkotó egyértelmű álláspontot tett a jogerő(re képesség) mellett, hiszen éppen a kártalanítási eljárással összefüggésben a 75/N. § (9) bekezdése kifejezetten akképp rendelkezik, hogy a büntetésvégrehajtási bíró a jogerős határozatot a jogerőre emelkedést követő tizenöt napon belül megküldi az igazságügyért felelős miniszternek. A kifizetési szabályok körében

\footnotetext{
${ }^{56}$ A 2020. december 31. napjáig hatályban volt Bv.tv. kártalanításra vonatkozó szabályai még ilyen érdemi vizsgálat nélküli elutasítási okot nem szabályoztak. Ennek ellenére azonban az a gyakorlat alakult ki, hogy ha a kérelmező olyan időszakot jelölt meg a kérelmében, amelyet illetően már bv. bíró elbírált akként - érdemben -, hogy kártalanítást állapított meg részére, akkor nem érdemi vizsgálat nélkül, hanem "simán" elutasításra kerültek az ilyen kérelmek. (Hivatkozással az akkor hatályban volt Bv.tv. 10/A.§ (2) bekezdésében foglaltakra, mely szerint kártalanításként meghatározott jogcímen további kártérítésnek vagy sérelemdíjnak helye nincs, de az elítélt jogosult az ezt meghaladó igényét polgári bíróság előtt érvényesíteni.)
} 
ugyancsak ezt megismétli, amikor a 75/O. § (1) bekezdése kimondja, hogy a kártalanítással összefüggő kifizetés iránt az igazságügyért felelős miniszter intézkedik a bv. intézet határozatának vagy a büntetés-végrehajtási bíró jogerős ügydöntő végzésének (a továbbiakban együtt: kártalanítási döntés) az igazságügyért felelős miniszterhez történő érkezésétől számított a) kilencven napon belül, b) a 75/R. $§(1)$ bekezdése szerinti esetben százhúsz napon belül.

A kifejtettek okán - főleg a Kúriai határozatokban foglalt érvelésekre figyelemmel - mindenképp fel kell tenni a kérdést, hogy a bv. bírói határozatok jogerejével vagy véglegessé válásával kapcsolatos ellentmondások mégis miképp oldhatóak fel. Mi lehet a megoldás? Úgy vélem, hogy a jelenlegi jogszabályi környezetben nem lehet pusztán a gyakorlatra bízni azt, hogy találja meg a "helyes" értelmezést. Ennek az az oka, hogy bármelyik értelmezési irányba történő elmozdulás jogszabályi zsákutcába vezet. Erre tekintettel úgy gondolom, hogy mindenképp jogalkotási szinten lehet megoldásra törekedni.

Felvetődhet az az alternatíva, hogy a Bv.tv. 50. § (1) bekezdés f) pontjából kikerüljön az „ügydöntő" szó. Ugyanakkor, ha fennmarad a bv.tv. $50 . \S(6)$ bekezdése szerinti azon szabály, hogy a Be.-t háttérjogszabályként kell alkalmazni, akkor annak 456.§ (1) bekezdése szerint pláne nem lehetne beszélni bv. bírói ügydöntő határozatról, ennek eredményeképp akkor a bv. bírói határozatokat véglegessé válónak kellene tekinteni, ami pedig az anyagi jogerőhatás hiányával kapcsolatos problémákat vethet fel.

Gondolhatunk arra is, hogy a Bv.tv. $50 . \S(6)$ bekezdésében foglalt szabályt kellene "finomítani". Esetleg a "Ha e törvény, vagy más törvény eltérően nem rendelkezik" szövegrész helyébe az kerülhetne, hogy „Az e törvényben külön nem szabályozott kérdésekben". Ebben az esetben talán a Bv.tv. 50.§ (1) bekezdés f) pontjában megmaradhatna az "ügydöntő" szó úgy, hogy annak helyére "e törvény szerinti ügydöntö" szövegrész kerülne. Mindezek mellett ugyanakkor továbbra is szükségtelennek tartanám a Bv.tv. 50.§ (1) bekezdés fb) és fc) alpontjaiban "a jogerőre emelkedést követően" szövegrész hatályban tartását, hiszen elegendő, ha a törvényesség érdekében bejelentett jogorvoslat kapcsán beidézzük a be. azon szabályát, amely alapján egyértelműn lehetővé teszi a jogszabály a véglegessé váló határozatokkal szemben is ezen jogorvoslatot. Ugyanakkor még mindezek fényében továbbra is fennmarad az az ellentmondás, hogy amennyiben ily módon tennék jogerőre képessé a bv. bírói határozatokat, akkor az anyagi jogerő ekképp már nem csupán a kimerített váddal (elbírált cselekményre) összefüggésben állhatna fenn.

Nem csupán az alapvető jogokat sértő elhelyezési körülmények miatti kártalanítási határozatok jogerejéről vagy véglegessé válásáról tartom szükségesnek a szakmai konzultációt, hanem a többi bv. bírói határozat kapcsán is véleményem szerint állást kell foglalni az említett kérdéskörben, hiszen látható, hogy akár alkotmányjogi panaszeljárás keretében komoly jelentősége lehet annak, hogy milyen gyakorlat kerül kialakításra. Reményeim szerint sikerült hozzájárulnom ahhoz, hogy egy újabb tudományos vita és diskurzus vegye kezdetét a jogerő akár jogágakon is átívelő dogmatikája kapcsán. 